\title{
Geçmişten Günümüze Erzurum Çeyiz Geleneği
}

\section{Erzurum Dowry Tradition from Past to Present}

\section{Züleyha Mutluer}

Yüksek Lisans Öğrencisi, Kocaeli Üniversitesi Sosyal Bilimler Enstitüsü, Türk Dili ve Edebiyatı Bölümü

email: mutluer.zuleyha@gmail.com DORCID ID: https://orcid.org/0000-0003-2413-6474

\section{Mine Can}

Doç. Dr., Kocaeli Üniversitesi Değirmendere Ali Özbay Meslek Yüksekokulu El Sanatları Bölümü email: mine can82@hotmail.com (DORCID ID: https://orcid.org/0000-0001-6563-7174

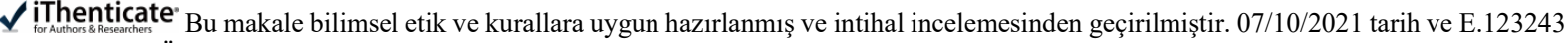
sayılı Kocaeli Üniversitesi Sosyal ve Beşeri Bilimler Etik Kurulu onayı alınmıştır.

Atıf (APA 7)/To cite this article

Mutluer, Z., \& Can, M. (2021). Geçmişten günümüze Erzurum çeyiz geleneği. Atatürk Üniversitesi Güzel Sanatlar Enstitüsü Dergisi, 27(47), 400-409. https://doi.org/10.35247/ataunigsed.948350

Makale Gönderim Tarihi/Received: 05/06/2021

Makale Kabul Tarihi/Accepted: 09/10/2021

Makale Yayın Tarihi/Published: 28/10/202

Research Article / Araştırma Makalesi

Öz

İnsan hayatının geçiş dönemlerinde ritüeli en bol olan evlenme olay1 toplumdan topluma gerek uygulamalar bazında gerek aşamalar bazında farklılıklar göstermektedir. Evlenme olayı bireylerin sosyalleștikleri ilk kurum olan aile birliğini olușturması açısından tüm toplumlarda önemli görülmektedir. Bu sebeple evlenmenin gerçekleşebilmesi bazı şartlara ve ritüellere dayandırılmaktadır. Toplumlar arasında farklılık gösteren evlenme şartlarından birisi de çeyizdir. $\mathrm{Bu}$ araştırmada Anadolu'nun birçok yöresinde varlığı tespit edilen çeyiz geleneği bağlamında, Erzurum yöresinde geçmişten günümüze çeyiz geleneği ele alınarak değerlendirilmiş̧ir. Çalışma tarama ve alan arastırması modeline dayalı betimsel bir araștırmadır. Erzurum'da geleneksel yapıya bağlı olan yöre halkı çeyizin sürdürülmesinde aktif durumdadır. Evlenecek kızların eş dost akrabalarının desteğiyle özellikle el sanatı ürünlerine dayalı olarak hazırladıkları çeyiz, yörede oldukça önemsenmekte ve kadim bir geleneğin devamı olarak yöre halkı tarafından sürdürülmektedir. Araştırma kapsamında Erzurum çeyizlerinde bulunan eşyalar geçmişten günümüze tespit edilerek ele alınmıştır. Çeyizlerde yer alan işleme, örme, dokuma ve deri el sanatı ürünler ile hazır eşyalar tespit edilmiş ve kaynak kişilerden elde edilen bilgi ve görseller eşliğinde sunulmustur. Ayrıca ceyiz geleneği içerisinde tarihsel süreçte değişen ve kaybolan folklorik unsurlar, toplumsal veya kültürel boyutta ele alınarak literatürden elde edilen bilgiler doğrultusunda sunulmuştur.

Anahtar Kelimeler: Erzurum, Çeyiz, Gelenek, Evlenme, El Sanatlar

\begin{abstract}
Marriage which is the most abundant ritual in the transitional periods of human life, varies from society to society, based on practices and stages. The event of marriage is considered important in all societies in terms of forming the family union, which is the first institution where individuals socialize. For this reason, the realization of marriage is based on certain conditions and rituals. One of the marriage conditions that differ between societies is the dowry. In this research, in the context of the dowry tradition, whose existence has been determined in many regions of Anatolia, the dowry tradition in the Erzurum region from past to present has been evaluated. The study is descriptive research based on a survey and field research model. Local people, who adhere to the traditional structure in Erzurum, are active in maintaining the dowry. The dowry which is prepared by the girls, especially based on handicraft products, with the support of their spouses and relatives, is considered very important in the region and appears as a matter of importance by the local people as a continuation of an ancient tradition. Within the scope of the research, the items found in Erzurum dowry were determined and handled from the past to the present. Embroidery, knitting, weaving, and leather handicraft products and ready-made items in the dowry were identified and presented with the information and visuals obtained from the source persons. In addition, the folkloric elements that have changed and disappeared in the historical process in the dowry tradition are handled in social or cultural dimensions and presented in line with the information obtained from the literature.
\end{abstract}

Keywords: Erzurum, Dowry, Tradition, Marriage, Handicrafts

\section{Giriş}

Toplumu oluşturan en küçük sosyal kurum olan aile geleneklerin oluşmasında yerleşmesinde ve taşınmasında önemli bir unsurdur. İnsan hayatının geçiş dönemleri olarak belirtilen doğum, evlenme ve ölüm ise aile kurumunu yakından ilgilendiren ve çeşitli ritüelleri bünyesinde barındıran önemli olaylardır. Ailenin kurulması bu geçiş dönemlerinden evlenme olayı ile gerçekleşmektedir. Evlenme tüm toplumlarda görülen bir geçiş dönemi olmakla birlikte toplumların geleneklerine, kültürlerine göre birtakım farklılıklar göstermektedir. Bu farklılıklar ülkeler, iller, hatta köyler arasında bile değişkenlik gösterebilmektedir.

Evlenme döneminin toplumlara göre farklılık gösteren en önemli unsurlarından birisi de çeyizdir. Çeyiz kelimesi Arapça'da gelinin, yolcunun ve sefere çıkacak olan ordunun gereksinim duyacağı gıda maddesi, silâh, eşya vb. malzemeler anlamındaki cehâz (cihâz) kelimesinden Türkçeye geçmiş, çehiz ve çeyiz şeklinde yaygınlık kazanmıştır (Mahmûd ed-Dîb, 1993, s. 296-297). 
Antropoloji sözlüğünde çeyiz, "Ataerkil topluluklarda, evlenerek haneden çıkacak olan kızın mirastan payını önceden alması ve sonrasında erkekler çocuklar arasındaki miras paylaşımının dışına çıkarılması" şeklinde açıklanmaktadır (Emiroğlu ve Aydın, 2003, s. 195).

Türk Dil Kurumu sözlüğünde ise gelin için hazırlanan her türlü eşya, cihaz olarak tanımlamıştır (TDK, t.y.).

Çeyiz dünyadaki birçok toplumda karşılaşılan bir uygulamadır. İsim olarak farklılık gösterse de yapılan tanımlarla uyumlu uygulamalara farklı kültürlerde rastlanmaktadır. Akadca' da hediye etmek anlamına gelen šarāku fiilinden türetilen šeriktu(m)/širiktu(m) kelimesi çeyiz anlamına gelmektedir. Eski Babil dönemine ait olan birçok metinde çeyiz geleneğinin varlığı, hatta bu geleneğe ait içeriğin listesine rastlanmaktadır (Toptaş, 2019, s. 409-414). Çeyizin geçmişten günümüze uzanan tarihi ve sosyal düzeni incelendiğinde; Hititlerde çeyizin karşıllğı olan ivaru kelimesi ile tekstil ürünleri, mal mülk, hayvan sürüleri ve sivil esirlerden işçiler verilmesi; Sümerlerde evlenen kıza babası tarafından çeyizle birlikte 19 gümüş para ve köle verilmesi; Ortaçağ Avrupa'sında çeyizin, evlenecek kızın, erkeğe evliliğin ağır yükünü karşılamak ve ebediyen kendisinde kalmak üzere vereceği bir bağış olarak görülmesi; Rönesans'ta cassoni denilen çeyiz sandıklarının üzerine varlıklı ailelerin armalarının işlenmesi ve satılamaz mülklerden oluşması bu kültürün uzantılarının örnekleridir (Kademoğlu, 1999, s. 375-382).

Dünyada olduğu gibi Türk kültüründe de çeyiz geleneği köklü bir geçmişe sahiptir. Türk tarihinin ilk yazılı metinleri olan Orhun Kitabeleri'nde “cihaz ve kalın” kelimeleri yer almaktadır (Karakelle, 2008, s. 16). Kalın, oğlan evinden kız evine çeyiz hazırlamak üzere verilen ve adına başlık da denen parayı ifade etmektedir (Demir, 2017, s. 130). Hun Türklerinde kızların çeyizi yün, keçe ve deriden kaftan, giysi, çizme, börk, torba, sarkıntılı kemer ve eşyalardan oluşmaktadır. Ayrıca Hun Türklerinde en kıymetli hediye at olarak görüldüğü için evlenecek erkek, kız tarafına kalın olarak at veya davar süsleri vermektedir (Kademoğlu, 1999, s. 53).

Selçuklularda çeyiz kapsamında el işlemeleri, bakır mutfak eşyaları, çeyiz sandığı bulunurken ayrıca çeyizlik halının bir yerinde birkaç nazar boncuğu, dokuyanın saçından bir parça veya kıymetli bir elbiseden kesilmiş bir parça kumaşın bulunması da geleneksel bir uygulama olarak görülmektedir (Nutku, 1993, s. 297-298). Başdin (2017, s. 404) Selçuklu beylerinden Çağrı Bey'in kızı Arslan Hatun'un halife ile evliliğinde bulunan çeyizin içinde büyükbaş hayvanlar, kıymetli madenden yapılmış kaplar, para, bakire sekiz cariye, üzerlerinde mücevher işlenmiş kaftanlar bulunan katırların üstünde altı genç kız vs. bulunduğunu açıklamaktadır. Kademoğlu (1999) ise, Selçuklu Sultanlarından Melikşah'ın kızı Mehmelek Hatun, 1087'de Halife ile evlendiğinde gelinin cihazının yüz otuz deve yükü olduğunu, Mehmelek Hatun'un on iki sandık dolusu hazinesinde gelinin, atlas, dîbâ ve ipekli kumaşlardan yapılmış olan elbiselerini ise tam yetmiş dört katırın taşıdığını belirtmektedir (s. 61).

Osmanlı İmparatorluğu döneminde çeyiz geleneği sürdürülmeye devam etmiştir. Osmanlı Dönemi’nde kızların kendi mal varlığı sayılan çeyizlerini kendilerinin hazırlaması önemli görülür hatta bu aşamada kızlara cihazın (çeyizin) nasıl hazırlanacağına ilişkin eğitimler verildiği bilgisi mevcuttur. Ayrıca çeyizin gelin olacak kız tarafından hazırlanmayarak dışarıdan satın alınması durumunda ise ayıplandığı bilinmektedir (Demir, 2017, s. 129). El sanatları işin içine girince çeyiz hazırlamak büyük bir emek ve sanat ürününe dönüşmektedir. Bu anlamda çeyiz dünyanın en meşakkatli ve birbirinden farklı beceriler gerektiren mesleği olup, küçük yaşlardaki kızlar için bu sorumluluğun üstesinden gelmek oldukça zordur (Kademoğlu, 1999, s. 121).

Özellikle gelinin çeyizinde bulunan eşyaların göze güzel görünür şekilde serilmesi anlamına gelen "çeyiz yazma" geleneği Anadolu'nun bazı yörelerinde halen sürdürülmektedir (Balaman, 1983, s. 141). Gelinin çeyizinin sergilendiği çeyiz odaları Osmanlı döneminde kız evinin ekonomik durumunun bir nişanesidir. Sergilenen eşyalar içinde sandık çeyizi olarak; işlemeli başörtüler, havlu takımları, işlemeli yatak takımları, tülbentlerin yanı sıra damat için oyalı gömlekler, donlar, iç çamaşırı, kürk ve manto gibi giyim eşyaları, ayakkabılar; iğnedenlik, tarak kesesi, kaşık torbası, işlemeli tencere tutaçları, süpürge, faraş, ayna, mutfak kazanları ve tencereleri, sini, hamam tası, ibrik gibi günlük hayatta ihtiyaç duyulan ev eşyaları bulunmaktadır (Nutku, 1993, s. 297-298).

Günümüzde geleneksel yapısını koruyan ailelerde çeyiz geleneği halen sürdürülmektedir. Özellikle kırsal kesimde bu geleneğin etkisi yoğun olarak hissedilirken kentlerde geleneğin modernleşmiş farklı boyutlarıyla karşılaşılmaktadır. Kentlerde el emeği ürünlerin yerini; mutfak eşyaları, elektrikli ev aletleri, perde, halı ya da yatak odası mobilyası gibi günlük kullanımda ihtiyaca dönük ürünlerin aldığı görülür. Çeyizin maddi ve zaman boyutu ise hiçbir koşulda değişmeyen iki unsurudur. Her koşulda maddi bir güç gerektirir ve zamanla birikerek tamamlanır. Çeyizin oluşturulması uzun vadede gerçekleşir. Bu uzun zaman dilimi ise özellikle el işi olarak yapılan ürünlerin tamamlanması noktasında aileye kolaylık sağlamaktadır. Çeyizin temel mantığı geçmişten günümüze Türk ve dünya toplumlarında yeni kurulan aile birliğine maddi katkı sağlamaktır. Kız evine çeyiz hazırlığı aşamasında eş dost ve akrabaların da hediyeleriyle destek olduğu görülmektedir.

İnsan hayatının geçiş dönemlerinden biri olan evlenme kız ve erkeğin sosyalleşme sürecinin önemli bir aşamasını oluştururken aileler arasındaki dayanışmayı sağlaması ve toplumsal ilişkileri düzenlemesi açısından önemli görülmektedir (Örnek, 1995, s. 185). Evlenme sonucunda toplumun en küçük birimi olan aile kurulur. Bu nedenle de evlilik her aşamasıyla özenilen ve çeşitli ritüellerle beslenen önemli bir olay olarak görülmektedir. Kız kaçırma, 
oturak alma, beşik kertmesi, berdel, taygeldi, leviratif, sorarat, görücü usulü evlenme gibi çeşitli evlenme biçimleridir (Artun, 2019, s. 194-196). Modern yaşamın getirisi olarak günümüzde evlenecek olan kız ve erkeğin evlilik kararlarında söz sahibi oldukları görülmektedir (Altun, 2004, s. 196). Evlilik biçimlerinin farklılaşması çeyizin sergilenmesi noktasında da farklılıklar doğurmaktadır. Örneğin kaçarak evlenmede kızın çeyizi anne babanın kızına kırgınlığı veya küslüğü sebebiyle verilmemek dolayısıyla çeyiz serilmemektedir.

\section{Yöntem}

$\mathrm{Bu}$ çalışma tarama modeline dayalı betimsel bir araştırmadır. Ayrıca çalışmaya kaynak oluşturması için alan araştırması yapılarak kaynak kişilerle (KK) Erzurum el sanatları ve çeyiz geleneği üzerine görüşme yapılmıştır. Yapılan tüm görüşmeler araştırmaya katılan bireylerden izin alınarak yazılı olarak kayıt altına alınmıştır. Kaynak kişilerin Erzurumlu olması ve orada doğup, büyüyüp, yaşıyor olması daha güvenilir bilgi toplanmasına katkı sağlamıştır. Kaynak kişilerin bilgileri Tablo 1'de görülmektedir.

Tablo 1

Kaynak Kişilerin Demografik Bilgileri

\begin{tabular}{lcccc}
\hline Kod & İsim-Soyisim & Meslek & Yaș & Doğum \\
\hline KK1 & Halise Akbayır & Ev Hanımı & 61 & Erzurum \\
KK2 & İklime Atmaz & Ev Hanımı & 48 & Erzurum \\
KK3 & Sülbiye Akgün & Ev Hanımı & 52 & Erzurum \\
KK4 & Alime Bingöl & Ev Hanımı & 50 & Erzurum \\
KK5 & Hüsna Erdem & Ev Hanımı & 76 & Erzurum \\
KK6 & Mecbure Erdem & Ev Hanımı & 71 & \\
\hline
\end{tabular}

\section{Bulgular ve Yorum}

\subsection{Erzurum Çeyiz Geleneği}

Erzurum'da evlenme eylemi çeşitli yaptırımlar ve seremonilerle gerçekleştirilir. Evlenme çağına gelen delikanlı için annesi ve kadın akrabalarının yaptığı görücü gezme eylemiyle başlayan bu seremoniler kız bakma, kız isteme, söz kesilmesi, ağız tatlılığı da denilen erkek tarafının şeker ve çerez alarak kız evine gelmesi ve yapılan şerbetten ilk olarak erkek tarafından birinin içmesi (Türkmen, 1977, s. 566) şeklinde tertiplenen şerbet içme töreni ile başlar. İkram edilen şerbet için tepsiye erkek tarafından olan herkes para bırakır. Şerbet töreninde genellikle dini nikâh da kıyılır. Sonrasında nişan hamam takımı yollama, çeyiz serilmesi, kına gecesi, gelin hamamı, kısır gecesi, düğün, nikâh, gibi birçok aşamadan geçilerek tamamlanır. Kısır gecesi olarak adlandırılan aşama Erzurum'da düğünden önceki gece kadınların kına gecesi yaptığı esnada damadın farklı bir mekânda yakın arkadaşları ve akranlarıyla bir araya gelerek eğlendikleri eğlence törenidir (Yılar, 2011, s. 137). Bu aşamaların belki de en uzun vadede gerçekleştirileni ise çeyizdir.

Çeyizin tamamlanması "kız beşikte çeyiz sandıkta" ifadesinden de anlaşılacağı üzere kız çocuklarının bebeklik dönemlerinden itibaren hazırlanmaya başlanan bir birikimle gerçekleştirilir. Aileler kız çocuklarının çeyizi için ufak tefek hazırlıklar yaparak bunları saklarlar. Bu hem maliyet hem de zaman açısından ailelere kolaylık sağlamaktadır. Çeyizin içeriğinde bulunan el emeği ürünler özellikle çeyize verilen önemin bir nişanesidir. Erzurum'da çokça önemsenen çeyiz el içine karışacak olan kızın yüzünü ağartacak, ailesinin ise göğsünü kabartacak bir durum olarak değerlendirilir. Ayrıca ileride erkek tarafının çeyizle ilgili kızın gururunu kırıcı sözler söylemesinin böylece önüne geçilmiş olur. Aileler zaman zaman kendi ihtiyaçlarından dahi feragat ederek kızlarının çeyizini en güzel şekilde tamamlamaya çalışır. Çünkü çeyizin bir de sergilenme aşaması olacağını ve insanların da çeyizle ilgili olumlu veya olumsuz yorumlar yapacağını iyi bilirler.

Erzurum' da düğünler eskiden perşembe günü başlayıp bir hafta boyunca da devam etmekteydi. Çeyiz ise düğünün yapıldığı hafta pazartesi günü gelinin arkadaşları ve akrabaları tarafından kız evinde serilmekteydi. Kız akrabalarının çeyizi görmeye gelirken çeyize de katkı sağlamak amacıyla hediye getirdiği ve bu hediyeye de "saçı" adı verildiği bilinmektedir. Serilen çeyiz cuma gününe kadar toplanmazken cuma günü erkek tarafi ile komşularının büyükleri gelerek çeyizin listesini yapmaktadır. Buna da "çeyiz yazma" denir. İki ailenin de onayı alındıktan sonra liste kızın babasına verilir ve bu işlemin ardından çeyiz toplanarak damadın evine veya gelinin yaşayacağı eve gönderilmektedir (Türkmen, 1977, s. 567).

Günümüzde ise düğünden on beş, yirmi gün önce kız evinin müsait bir odasına kızın akrabaları ve arkadaşları tarafından çeyiz serilmektedir. Çeyizin seriliş biçimi önemlidir. Her bir ürün kendi içinde sınıflandırılır ve çeyizi görmeye gelenler için çeyiz odası nizami bir şekilde düzenlenir.

Erzurum'da her kızın çeyizinde mutlaka bulunması gereken temel eşyalar vardır. Bunlardan ilki Kur'an-1 Kerim'dir. El emeğine dayalı özel bir kılıf içerisinde çeyizin başköşesine yerleştirilir. Kız çeyizinin olmazsa olmaz eşyalarından bir diğeri ise çeyiz sandığıdır ve her çeyizde mutlaka bulunması gerekir. Ayrıca bu sandığın ceviz ağacından olması da önemli bir husustur. Çeyiz sandığı gelinin mahremidir. Bu nedenle çeyiz sandıklarının kilitli olması dikkat çeken bir ayrıntıdır. Eskiden çeyiz erkek evine gönderileceği zaman çeyiz sandığının anahtarı 
kayınvalideye verilirdi (KK1). Bunların dışında çeyizin sergilenişinde seccadeler ve namaz örtüleri iplere asılırken, perde veya duvara gerilmiş koyu renkli bir bezin üzerine ise danteller iğnelenir. Böylece gelenler her ürünü detaylıca görmüş olur. İşlemeli havlular, çeşitli tekniklerle (iğne oyası, mekik, boncuk oyası, tığ oyası...) yapılmış oyalı yazmalar, el örgüsü çorap ve patikler desteler halinde sergilenir. Ayrıca ehram, yatak örtüsü takımları, yorganlar, bohçalar, hamam takımı gibi diğer eşyalar, mutfak eşyaları, halılar da çeyizin içinde sergilenen diğer ürünler arasındadır. Eskiden kız çeyizlerinde altı adet halı yastığı ve bir adet halı bulunur ve bu eşyalar o çeyizin demirbaş eşyaları olarak kabul edilirdi (KK1).

Çeyizin serildiği haberi davetlilere duyurulur ve böylece çeyiz odası davetlilere açılır. Çeyizi görmeye gelenler yanlarında saçı getirirler. Bazen saçı yerine para verildiği de olur. Bu süreçte yakın akrabalar da kızın eksiği olup olmadığını aileye sorarlar ve çeyizin eksiğini tamamlamak için gönüllü olurlar. Böylece Anadolu kültürüne hâkim olan sosyal dayanışma bir kez daha vuku bulmuş olur. Yaklaşık on gün kadar çeyiz, gezilmeye açık kalır. Çeyizin toplanma aşamasında gelinin yeni evinde damat tarafına vereceği hediye bohçaları hazırlanır. Eski adetlerde özellikle kendisine nişanlıyken bilezik takan kişilere hediye edeceği bohçaya mutlaka takılan bilezik sayısınca ehram ve karyola takımı konurdu (KK1). Çeyiz toplamanın ardından erkek tarafı davul zurna eşliğinde çeyizi götürmeye gelir bu aşamada kız evinin erkek tarafına yemek ikram etmesine "çeyiz ekmeği”" denir (Altuniş Gürsoy, 2016). Çeyizin evden çıkarılmasındaki bir diğer adet ise sandığa oturma âdetidir. Gelinin varsa kardeşi yoksa kuzeni çeyiz sandığının üstüne oturur ve bahşiş olarak para ister. Genellikle eğlenceli anların yaşandığı bu adette istediği parayı alan kardeş sandığı erkek tarafına vermeye razı olur. Çeyizin kız evinden çıkan ilk eşyası Kur'an-1 Kerim olur. Bazı aileler kızın bahtının aydınlık olması amacıyla Kur'an-1 Kerim ile birlikte evden ayna da çıkarırlar. Günümüzde çeyizin taşınacağı arabaların aynalarına havlu veya kurdele asılır. Çeyiz arabasına eşyalar dikkatli bir şekilde yüklenir ve yeni evli çiftin yaşayacağı eve götürülür.

Eşyaların kız evinden taşınmasıyla bitmeyen çeyiz seremonisi çeyiz eşyalarının yeni eve taşınması ve yerleştirilmesi aşamalarında da devam etmektedir. Çeyiz gelmeden önce ev detaylıca temizlenir ve eşyaların yerleştirilmesine hazır hale getirilir. Yeni eve ilk olarak Kur’an-1 Kerim ve ayna, sonrasında eşyalar büyük bir titizlikle yerleştirilmektedir. Gelinin yatak odasına erkek tarafından kimse girmez ve sadece kızın arkadaşları ya da akrabaları yerleştirme işlemini yaparlar. Yemek takımı masanın üzerine sığdığı kadarıyla sofra düzenince koyulmakta ve yastıklar, işlemeleri görülecek şekilde gardırobun üzerine dizilmektedir. Çeyiz yerleştirildikten sonra erkek tarafi çeyizi yerleştirenlere yemek ve çay ikram ederler. Son düzenlemeler de yapıldıktan sonra çeyizi yerleştirenler iyi dileklerde bulunarak evden çıkarlar. Günümüzde birçok çeyiz bu şekilde serilirken eskiden çeyiz sadece kız evinde sergilenmekte ve toplanıp yazıldıktan sonra erkek tarafına teslim edilmekteydi. Gelin ise yeni evini ancak evlendikten sonra görebilirdi (KK1).

\subsubsection{Erzurum Çeyizlerinde Yer alan Eşyalar}

Çeyiz hazırlamak hem uzun zamanda tamamlanması hem de ekonomik anlamda külfetli olması açısından oldukça yorucu olsa da, hazırlama aşaması bir genç kızın hayallerini, el emeği ve göz nurunu işlediği süreçtir. Bir kız çeyizinin hazırlanma sürecinde en fazla zamanı el emeği ürünlerin hazırlanması alır. Bu aşamada Erzurum çeyizlerinde yer alan el sanatı ürünleri belirli başlıklar halinde incelemek mümkündür.

\subsubsection{1. İşlemeli Çeyiz Eşyaları.}

Erzurum çeyizi işleme örnekleri açısından zengin bir örneklem oluşturmaktadır. Kanaviçe başta olmak üzere delik işi, Maraş işi, çin iğnesi, kum işi gibi elde ve makinede yapılan işlemeler yöre çeyiz kültüründe dikkat çekmektedir (Karakelle, 2008, s. 27).

Üst üste ve yan yana sıralanmış birbirini çarpı şeklinde kesen formlardan oluşan kanaviçe bir işleme tekniğidir (Can, 2017, s. 321). Yapılışının kolay ve keyifli olması sebebiyle Erzurum'da kız çocuklarına ilk öğretilen el işi tekniği olan kanaviçe çeyizlerde sıklıkla karşılaşılan ve ürün çeşitliliği fazla olan bir işleme türüdür. Eskiden karyola takımı, halı yastığ 1 yaygısı, sandık, bavul örtüsü, yorgan ağzı, çarşaf, mutfak ve vitrin takımlarında görülen kanaviçe, günümüzde modernize edilmişs şekilde pike, nevresim ve salon takımlarında tercih edilmektedir. Erzurum kanaviçe işlemelerinde en çok kullanılan motifler yöresel adlarıyla dağla bağ, dostum, kara üzüm, lale, leylak, karanfil, üzüm, gül, menekşe, binbir çiçek, arpalar gibi bitkisel motifler ve sepet, fiyonk, çelenk, kurdele motifleridir. Özellikle kanaviçe karyola takımları eskiden altın takan kişilerin bohçalarına mutlaka konulan eşyalar arasındadır (KK1). 


\section{Görsel 1}

Erzurum Yöresine Ait "Dostum” Adlı Kanaviçe Motifiyle İşlenmiş ve Kenarı Tĭg Danteli ile Süslenmiş Karyola Eteğinden Detay (KK1)

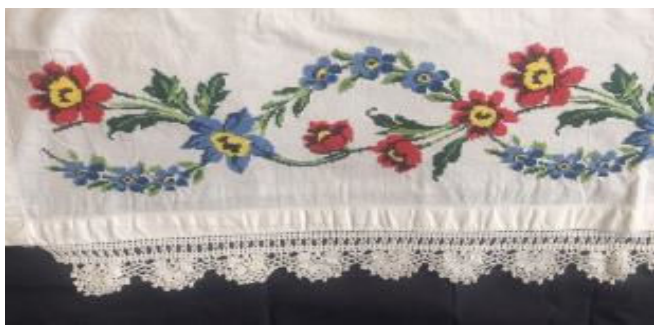

(Mutluer, 2021)

\section{Görsel 2}

Erzurum Yöresine Ait “Mor Menekşe” Adlı Kanaviçe Motifiyle İşlenmiş ve Kenarı Tı̆̆ Danteli İle Süslenmiş Karyola Eteğinden Detay (KK1)

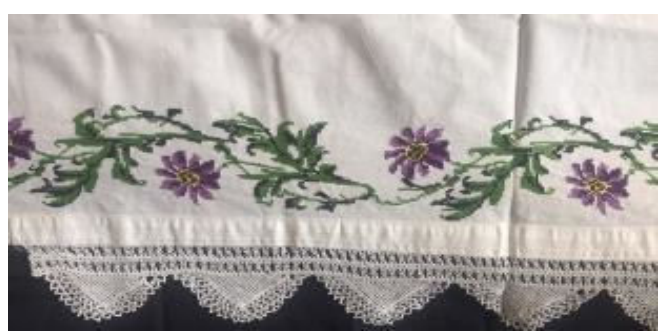

(Mutluer, 2021)

\subsubsection{2. Örme Çeyiz Eşyaları.}

Bir örgü sanatı olan oyalar işlendikleri ürünler açısından çeşitlilik göstermektedirler. Erzurum yöresinde genellikle yazma (tülbent), havlu, bohça, namaz örtüsü kenarına işlenen oyalar arasında iğne, mekik, boncuk, tığ cağ ve firkete oyaları görülmektedir. Bu oyalar içinde de en kıymetli görülen ve çeyize değer kattığı düşünülen oya iğne oyasıdır. İğne oyaları yazmalar ve namaz örtüleri başta olmak üzere havlu ve bohça kenarlarında da görülmektedir. Bitkisel bezeme ve geometrik motiflerin tercih edildiği oyaların yörede yonca, mor menekşe, karanfil, lale, karpuz, limon, kiraz, biber, karadut, elti patlatan, çavuş sırması, gelin tacı, gelinparmağı, mısır püskülü gibi yöresel benzetmelerle adlandırıldıkları da edinilen bilgiler arasındadır (KK1).

\section{Görsel 3}

Erzurum Çeyizinden Oyalı Tülbent Örnekleri (KK4)

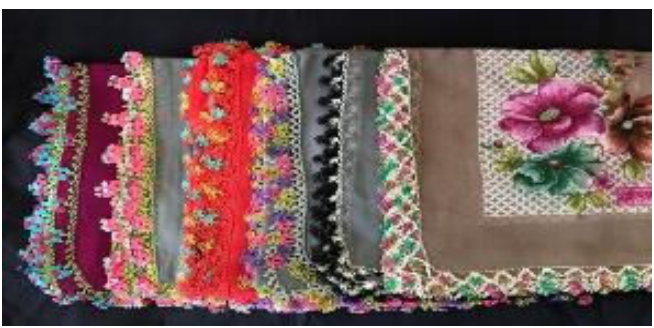

(Mutluer, 2021)

\section{Görsel 4}

Erzurum Çeyizinden Oyalı Mutfak Havlusu Örnekleri (KK2)

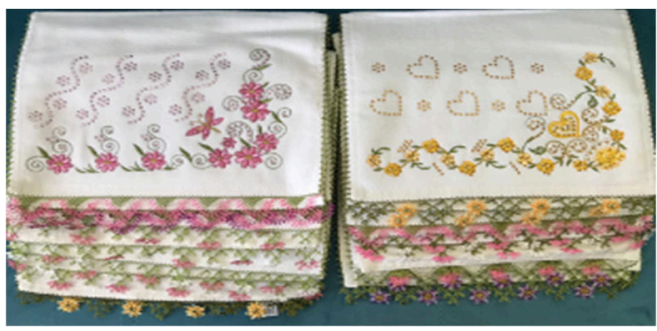

(Mutluer, 2021) 
İnce örgüler bağlamında değerlendirilen danteller Erzurum çeyizlerinde sıkça tercih edilmekte ve tentene adıyla da bilinmektedir. Dantel örgülerde ürün yelpazesi oldukça geniş olup yatak odası takımı, vitrin takımı, masa ve sehpa örtüsü, perde uçları, havlu kenarı, yastık kılıfı, yorgan ağzı, karyola takımı, peçetelik, iğnedenlik gibi neredeyse tüm ürünlerde dantelin kullanıldığı görülmektedir. Bitkisel ve geometrik motiflerin sıklıkla tercih edildiği danteller günümüzde de çeyiz eşyaları içinde hatırı sayılır bir yere sahiptir.

\section{Görsel 5}

Erzurum Çeyizlerinde Dantellerin Sergilenişi (KK1)

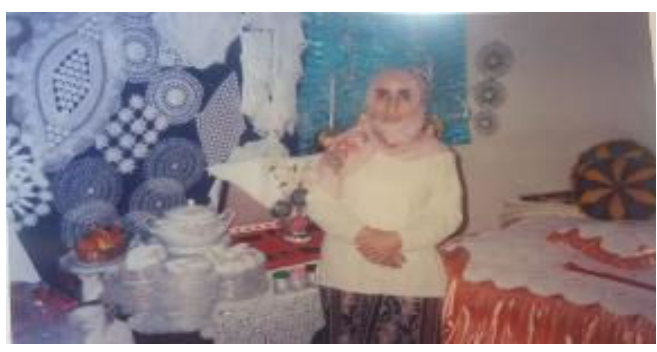

(Mutluer, 2021)

\section{Görsel 6}

Erzurum Çeyizinden Dantel Örnekleri (KK4)

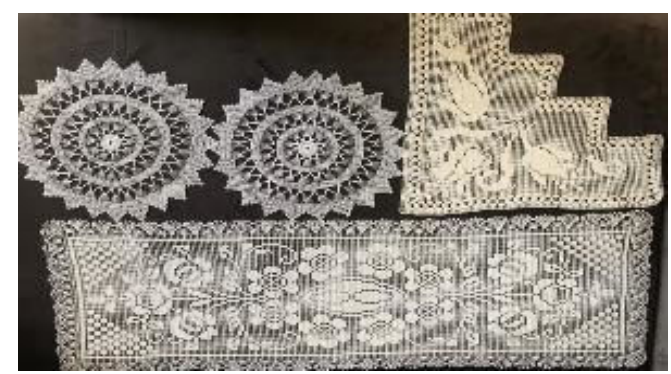

(Mutluer, 2021)

Erzurum'da kalın örgü olarak adlandırılan örgü çeşitleri kapsamında ise tığ, şiş, cağ gibi basit aletler kullanılarak çeşitli ipliklerle örülen yelek, hırka, patik ve çorap çeyizlerde demirbaş listesinde bulunmaktadır. Örme yelekler çeyizlerde kayınvalide, görümce ve eltilere hazırlanan bohçaların içine konulması sebebiyle mutlaka bulunmaktadır. Özellikle patikler desteler halinde en az on beş-yirmi adet olacak şekilde sergilenmektedir. Çorap ve patik yapımında genellikle beş şiş tercih edilmektedir. Erzurum'da kış mevsiminin çok soğuk ve uzun geçmesi ayrıca hayvancılığın gelişmiş olması hasebiyle yünden yapılmış giyim ürünleri tercih edilmektedir. Bu bakımdan yün çorap ve patikler Erzurum çeyiz kültüründe mutlaka bulunan giyim ürünleridir. Ayrıca yörede spor ve paddik (patik) olarak ifade edilen ve orlon ipliklerden örülen patik çeşitlerine de rastlanmaktadır (Karakelle, 2008, s. 54). Eskiden Erzurum çeyizlerinde damat, kayınpeder ve kayınvalide için özel olarak beyaz, kahverengi ve siyah ve renklerde yünden örülen ve "şal çorap" denilen çoraplar bulunmaktaydı. Kayınvalideninkine dizlere kadar olduğu için özel olarak "dizleme" denilen bu çoraplarda yöresel ifadeleriyle mum destesi, kâlmahlar, gudalar, örükler, saz yolu, acurlar, gibi motifler kullanılmaktadır (KK1). Kâlmah yörede harmandaki buğdayı samandan ayırmak amacıyla kullanılan bir çeşit elek olarak tanımlanmaktadır (KK1). Guda ise yörede küçük güveç olarak adlandırılmaktadır (KK1). Bu motife yörede "çukur burma" da denilmektedir (Karakelle, 2008, s. 57). Günümüzde ise bu ürünlere Erzurum çeyizlerinde rastlanmamaktadır.

\section{Görsel 7}

Erzurum Yöresine Ait Damat ve Kayınpeder İçin Örülen Çorap Örnekleri (KK4)

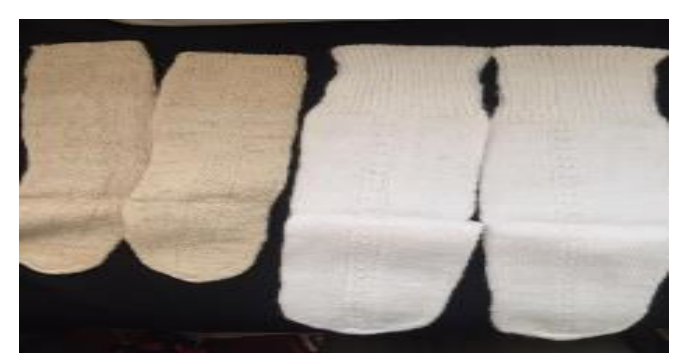

(Mutluer, 2021) 


\section{Görsel 8}

Erzurum Çeyizinden Patik Örnekleri (KK2)

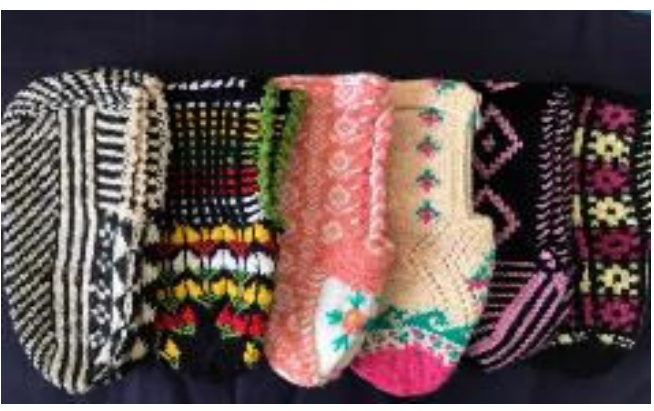

(Mutluer, 2021)

\subsubsection{Dokuma Çeyiz Eşyaları.}

Erzurum'da dokuma örnekleri olarak ehram, Keşanlı peştamal, halı, kilim, heybe, halı yastığ gibi ürünler görülmektedir.

\section{Görsel 9}

Erzurum Yöresine Ait Halı Yastığı ve “Dă̆-Bă̆” Adlı Kanaviçe Motifiyle Işslenmiş Yastık Yaygısı (KK5)

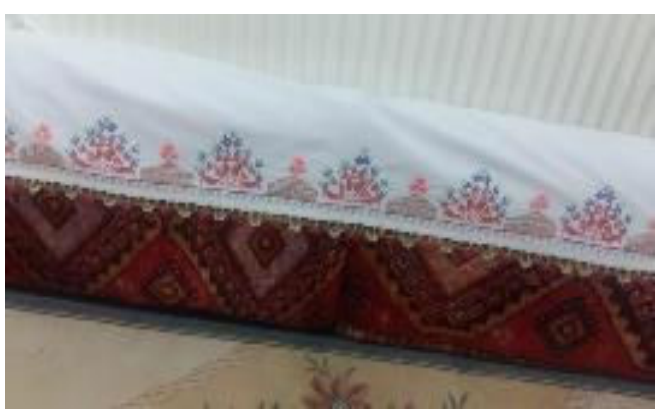

(Mutluer, 2021)

Erzurum çeyiz geleneğinde dokumanın en önemli örneklerinden biri ehramdır. Erzurum'da kadınların dışarı çıkarken üzerlerine sararak giydikleri kıyafet olan ehramlar çulfa adı verilen ustalar tarafından yapılmaktadır (Kayserili, 2014, s. 242).

Erzurum çeyizinde ehram mutlaka bulunmaktadır. Eskiden çeyizlerde en az beş altı tane ehram bulunur ve altın takan yakın akrabalara "çeyiz dağılma" adı altında bu ehramlar dağıtılırdı (KK1). Ehram giyen kadınların giydikleri ehramlar sosyal durumlarına göre çeşitlilik göstermektedir. Genç kızlar beyaz ve desensiz, nişanlı olanlar herhangi bir nakışlı ve beyaz, yeni evliler saat kordonu nakışlı ve beyaz, çocuklu olanlar boz renkli ehrama mavi nakışlı, hacı olanlar mor veya kahverengi ehrama yeşil nakışlı, yaşlılar ise düz veya sade nakışlı siyah ehram kullanmaktadır. Eskiden, ölen kadınların ehramlarını tabutlarının üstüne örtme geleneği bazı yörelerde halen daha sürdürülmektedir (Karakelle, 2008, s. 62-63). Ayrıca gelin baba evinden, dört kişi tarafindan tutulan gerilmiş ehramın altından geçerek çıkmaktadır. Bu geleneğe ise yörede "ehram tutma" adı verilmektedir. Eskiden gelin kırmızıya boyanmış "al ehrama” bürünerek baba evinden çıkmaktaydı. Bu gelenek ise günümüzdeki al duvak ile evden çıkmanın benzeri bir ritüeldir. Bu ritüel gerçekleştirilirken de şöyle bir mâni söylenir:

"Al ehram iki kanat

Ben söyleyim sen anlat

Mahallenin beyleri

Anam size amanat" (KK1)

Erzurum ehramlarında yöresel ifadeleriyle pirinçdeni, cevizkanadı, uçan kuş, çark yıldızı, saat kordonu, elma şeleği, arı dala kondu, saç örgüsü, elmas küpe, yıldızın oynayışı, kişniş çöpi (hanımeli), mercimek, ceylan boynuzu, mum desteği, tavan, hurma, reyhan dalı gibi nakışlar kullanılmaktadır (Salman ve Kırkıncıoğlu, 2014, s. 45). 
Görsel 10

Erzurum Çeyizlerinden Ehram Örneği (KK3)

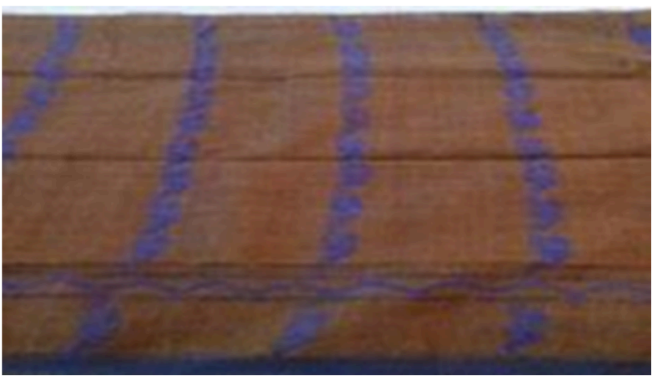

(Mutluer, 2021)

Keşanlı peştamal ise Erzurum çeyizinde mekikli dokumalardan olup hamama giden kadınların yanlarında mutlaka götürmeleri gereken bir çeyiz eşyasıdır. Özellikle hamam takımının içinde yer almaktadır (Karakelle, 2008, s. 63).

Erzurum çeyizlerinde bulunan dokuma ürünlerinden bir diğeri ise yörede iş yaparken bele bağlanan uzun, geniş dokuma olan şal tastarının (KK1) üzerine bağlanan çarpana bağıdır. Günümüzde rastlanılmayan bu dokuma ürünü çözgü iplikleri geçirilip gerilmiş çarpanaların kendi etrafında döndürülmesiyle çözgü iplikleri arasında oluşan ağızlıktan, atkı ipliklerini geçirip sıkıştırma yöntemiyle yapılmaktadır (Kılıç Karatay, 2019, s. 4). Günümüz Erzurum çeyizlerinde bulunmayan bu ürün eski çeyiz geleneklerinde görülmektedir.

\section{Görsel 11}

Erzurum Çeyizinden Çarpana Bă̆ı Örneği (KK6)

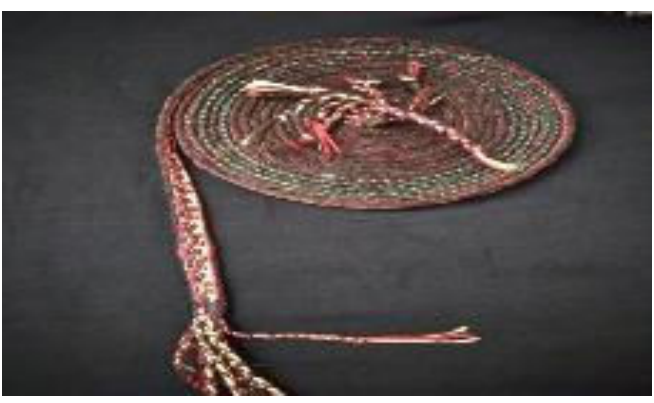

(Mutluer, 2021)

\subsubsection{Deri Çeyiz Eşyaları.}

Deri kullanılarak oluşturulan çeyiz ürünlerine Erzurum yöresinde pek rastlanılmamakla birlikte eskiden kumaş, deri ve yün kullanılarak oluşturulan iğnedenlikler dikkat çekmektedir. Bu iğnedenliklerde kumaş üzerine basit süslemelerle işlenen motifler süslenmekteydi. Görsel 12'de görülen iğnedenlik 1970'li yıllara ait olup yapımında deri kullanılmış bir örnektir (KK2). Erzurum'da eskiden her kadının cebinde iğnedenlik bulunması ise elzemdir (KK1).

\section{Görsel 12}

Erzurum Yöresine Ait İ̆nedenlik Örneği (KK2)

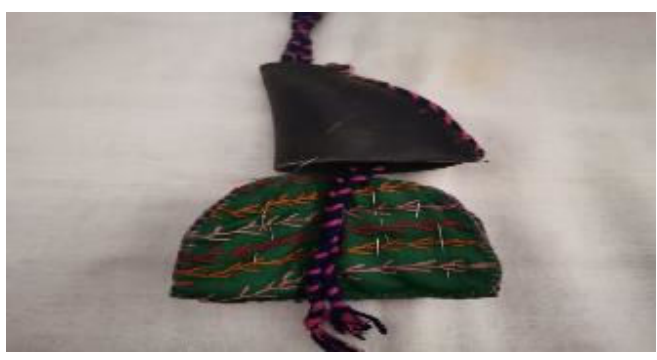

(Mutluer, 2021)

\subsubsection{Hazır Eşyalar.}

Çarşı çeyizi olarak da bilinen bu ürünler ise daha çok belirli bir ücret karşılığında satın alınan ürünleri kapsamaktadır. Değişen yaşam şartlarıyla birlikte hazır ürünlerin de kapsamı genişlemiştir. Önceden kız evinin alacağı eşyalar genellikle ufak tefek pahada çok da ağır olmayan eşyalar iken, günümüzde gelişen teknolojinin de 
etkisiyle beyaz eşyalar, elektrikli küçük ev aletleri gibi eşyalara dönüşmüştür. Ayrıca yine hazır ürünler grubunda değerlendirilen mobilyalardan olan yatak odası mobilyası, kız evinin çeyize eklediği hazır ürünler grubu arasına girmiştir. Bunların dışında tencere takımları, yemek ve kahvaltı takımları, çatal kaşık bıçak takımları, giyim ürünleri, yorgan, çeyiz sandığı, çeşitli giysiler, valiz gibi ürünler de hazır olarak çeyize eklenmektedir. Ayrıca takılar da çeşitli motif ve desenleri bünyesinde barındırması noktasında çeyiz ürünleri kapsamında değerlendirilmektedir (Karakelle, 2008, s. 72).

Yörede takılar evlenecek olan çiftlerin günlük ihtiyaçlarını karşılamaktan ziyade geleceğe yönelik bir yatırım olarak düşünülmektedir. Erzurum çeyizlerinde en dikkat çeken ve yöresel olan takılar "Erzurum burması" olarak adlandırılan yüzük ve bileziklerdir.

\section{Görsel 13}

Erzurum Burması Bilezik Örneği (KK1)

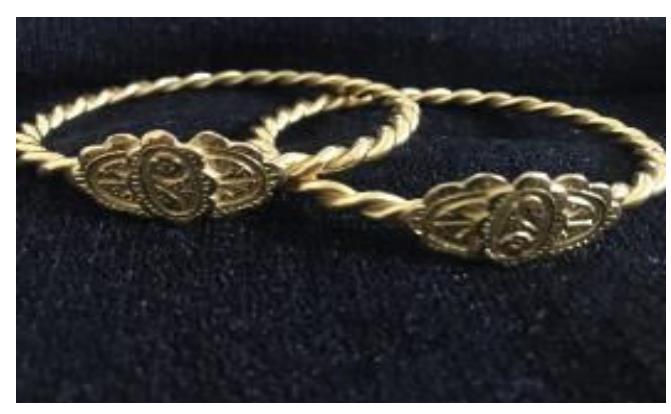

(Mutluer, 2021)

\section{Görsel 14}

Erzurum Burması Yüzük Örneği (KK1)

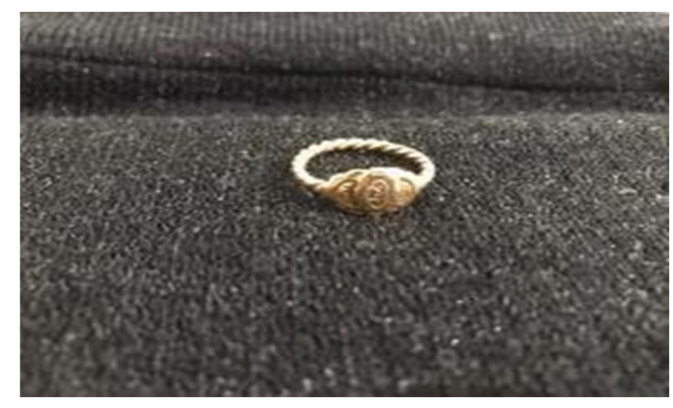

(Mutluer, 2021)

\section{Sonuç}

Gelenekler özellikleri itibariyle dinamik yapılı uygulamalardır. Zamanla değişebilir, gelişebilir hatta yok olabilirler. Türk ve dünya tarihinde kadim bir gelenek olarak karşımıza çıkan çeyiz geleneği de ortaya çıktığ toplumlarda gerek uygulama gerekse amaç bakımından farklılıklar göstermektedir. Bu bilgiler 1şığında örneklem olarak seçilen Erzurum yöresinde geçmişten günümüze değişen ve yok olan bazı uygulamaların varlığı tespit edilmiştir. Anadolu kültüründe benzer uygulamalarına rastlanan kız çocuklarının küçük yaşlarından itibaren başlayan çeyiz hazırlama serüveni Erzurum'da da görülmektedir. Hatta kız çocuklarına anneleri tarafından el işi teknikleri çeyiz hazırlama aşamasında öğretilmektedir. Erzurum çeyiz kültüründe geçen zamanla birlikte çeyiz yazma, çeyiz sandığı anahtarının kayınvalideye verilmesi, çeyiz ekmeği uygulamalarının günümüzde sürdürülmediği tespit edilmiştir. Ayrıca eskiden çeyizlerde bulunan çarpana bağı, iğnedenlik, halı yastığı gibi eşyaların da günümüz çeyiz listelerinde yer almadığı rastlanılan bulgular arasındadır. Çeyiz sandığı veya bohçasında yer alan ürünler de zamanla değişiklik göstermiştir. Özellikle makyaj malzemeleri kişisel bakım ürünleri, giyim eşyaları gibi günlük kullanıma uygun ihtiyaçların çeyiz listelerine girmesi dikkat çekmektedir. Kadının çalışma hayatında aktif rol alması geleneklerine sıkı sıkıya bağlı olan Erzurum insanının da çeyiz algısını değiştirmeye başlamıştır. Çeyiz hazırlayacak vakti olmayan ve ekonomik bağımsızlıklarını kazanan genç kızlar çeyiz için gerekli görülen el sanatı ürünlerini el işi yaparak geçimini sağlayan kadınlara yaptırmaktadırlar. Bu durum da aile ekonomisine katkı sağlamak isteyen ev hanımlarına ek gelir kapısı açmaktadır. Erzurum çeyiz listelerinde diğer bölgelerde de görülen hazır ürün yelpazesi artmıştır. Özellikle mutfak eşyaları ve küçük ev aletleri çeyizlerde değişimi dikkat çeken ürün gruplarıdır. Çeyizlerin içerikleri zamanla değişse de gelinlerin çeyizlerine olan özenleri günümüzde de değişmemiştir. Geleneklerine bağlı olan Erzurum yöresinde çeyiz serme adeti sürdürülmektedir. Kaynak kişilerden elde edilen bilgiler doğrultusunda işlevsel özellikleri modernize edilmiş 
el sanatı ürünlerinin Erzurum çeyizlerinde önemini hala koruduğu tespit edilmiştir. Yörede çeyizle ilgili yapılan yorumların günlerce sürmesi sebebiyle ailelerin çeyiz hazırlıkları yıllar boyu hazırlanan bir birikimle tamamlanmaktadır. Erzurum'da çeyiz geleneği genel olarak sürdürülmekle birlikte değişen ve kaybolan bazı unsurlar olduğu tespit edilmiştir. Folklorik özellikleri bünyesinde barındıran çeyiz geleneği aracılığı ile Erzurum'da yöresel birçok uygulama ve el sanatının sürdürülmesi gelenek ve göreneğin yaşatılmasına destek olmaktadir.

\section{Kaynakça}

Altun, I. (2004). Kandıra Türkmenlerinde doğum- evlenme- ölüm. Yayıncı Yayınları.

Altuniş Gürsoy, B. (2016, Ekim 11). Erzurum'da çeyiz dizme âdeti. Erzurum Haber Gazetesi. https://erzurumhabergazetesi.com/73423-erzurumda-ceyiz-dizme-adeti

Artun, E. (2019). Türk halkbilimi. Karahan Kitabevi.

Balaman, A. R. (1983). Gelenekler töre ve törenler. Betim Yayınları Halkbilim (Folklor) Dizisi.

Başdin, A. (2017). İçtimai gelenekler açısından Selçuklularda toy, düğün törenleri ve gelenekleri (Sultan Alp Arslan dönemi. Bilecik Şeyh Edebali Üniversitesi Sosyal Bilimler Dergisi, 2(2), 400406. https://dergipark.org.tr/en/download/article-file/369377

Can, M. (2017). Anadolu Türk kültüründe kanaviçe. Motif Akademi Halkbilimi Dergisi, 10(20), 319-334. https://dergipark.org.tr/en/download/article-file/398127

Demir, S. (2017). Sandık ve çeyiz kültürüne müzeografik (müze işlemleri) açıdan yaklaşmak. Folklor/Edebiyat, 23(89), 131-145. https://tinyurl.com/xrddn42y

Emiroğlu, K., \& Aydın, S. (2003). Antropoloji sözlüğ̈̈. Bilim ve Sanat Yayınları.

Kademoğlu, O. (1999). Çeyiz sandı̆̆ı. Duran Ofset.

Karakelle, A. (2008). Erzurum'da çeyiz geleneği üzerine bir araştırma (Tez No. 214853) [Yüksek Lisans Tezi, Gazi Üniversitesi, Eğitim Bilimleri Enstitüsü]. Yüksek Öğretim Kurulu Tez Merkezi.

Kayserili, A. (2014). Erzurum şehri’nin kültürel coğrafyast. Atatürk Üniversitesi Yayınları.

Kılıç Karatay, S. (2019). Yörüklerde çarpana dokuması. M. Şahin (Ed.), IV. uluslararası rating academy kongresi "Köy enstitüleri ve eğitimde yeni arayışlar" (s. 1-12) içinde. Rating Academy Yayınları. https://az.my1lib.org/book/5227077/aba450

Mahmûd ed-Dîb, A. (1993). Çeyiz. TDV İslam ansiklopedisi cilt VIII. Türkiye Diyanet Vakfı Yayınları. https://islamansiklopedisi.org.tr/ceyiz

Mutluer, Z. (2021). Çeyiz eşyası örnekleri [Fotoğraf]. Züleyha Mutluer Kişisel Arşivi.

Nutku, Ö. (1993). Çeyiz. TDV İslam ansiklopedisi cilt VIII. Türkiye Diyanet Vakfı Yayınları. https://islamansiklopedisi.org.tr/ceyiz\#2-osmanlilarda-ceyiz

Örnek, S. V. (1995). Türk halkbilimi. Kültür Bakanlığı Yayınları.

Salman, F., \& Kırkıncıoğlu, Z. (2014). Geçmişten günümüze Erzurum'da ehram (ihram) dokumacılığı. Arış Dergisi, 10, 42-51. https://dergipark.org.tr/en/download/article-file/660946

TDK. (t.y.). Çeyiz. Türk Dil Kurumu sözlükleri içinde. Türk Dil Kurumu Başkanlı̆̆ı. https://sozluk.gov.tr/

Toptaş, K. (2019). Akadca çivi yazılı belgelerde çeyiz. Türk Tarih Kurumu Belleten, 83(297), 407-427. https://dergipark.org.tr/en/download/article-file/964396

Türkmen, F. (1977). Erzurum'da düğün adetleri ve düğün türküleri. Türk Kültürü, 15(177), 565-572.

Yılar, Ö. (2011). Erzurum'da erkeklerin bekârlı̆̆a veda partisi “kısır gecesi”. Atatürk Üniversitesi Türkiyat Araştırmaları Enstitüsü Dergisi, 0(45), 137-158. https://dergipark.org.tr/tr/download/article-file/33559 